\title{
Analysis and Countermeasures of Psychological Problems of College Students in Private Colleges and Universities
}

\author{
Wang Shuqi, Zhu Guangliang* \\ School of Media, Xi'an Peihua University \\ Xi'an, Shaanxi 710125
}

\begin{abstract}
With the increase in the number of college students in private colleges and universities, more and more attention has been paid to the psychological problems of college students. This paper analyzes the common and special psychological problems between private college students and public university students from the point of students, and puts forward some ideas to solve the psychological problems, and provides the countermeasures to solve the problems for colleges, society, students and families, which can be used as reference to solve the psychological problems of private college students, improve the quality of personnel training and serve the society.
\end{abstract}

Keyword—private colleges and universities; university students; psychology; tactics

\section{INTRODUCTION}

With the rapid development of economy and society in our country, private colleges and universities have received the dividend of reform and developed rapidly in the tide of reform. The latest official data of the Ministry of Education [1] show that as of June 15,2019 , there were 2688 ordinary colleges and universities and 434 private undergraduate colleges and universities, accounting for $16.15 \%$. The quality of education and teaching in private colleges and universities has been steadily improved and gradually recognized by the society. It has become an important part of higher education in our country. In the process of development, private colleges and universities have gradually formed characteristics. Compared with public schools, the main sources of funding for running schools are tuition fees and school management, and the government has less economic support. The student's tuition standard is high, the same major tuition fee is far higher than that of the public school, generally 3-4 times higher, some even higher than 5-6 times[2], which is a great burden for students and families, and increases the mental pressure of the general students in the economic conditions. in that aspect of the quality of the students, most of the students of the non-governmental university are weak in learning, and the result of the college entrance examination is not ideal; some of the students work in a frugality to some extent and have a great psychological burden; in addition, the students of the private university lack the identity of the school, In addition, in the course of education and teaching, individual teachers can't guide correctly and the teaching quality is not high, which leads to The students have a great psychological burden. The problem of the mental health of the students in the private university is not only the individual problem but also the social problem, but the solution of these problems will have a great impact on the overall development of the students and the school reputation. Therefore, the work of the psychological education of the students of the private university has become an important work of the education and teaching of the private university, and also the important content of the students as the center, the psychological education is integrated into the whole process of education, the mental health level of the students is improved, and the students are prevented from overreacting.

\section{AN ANALYSIS OF THE PSYCHOLOGICAL PROBLEMS AND CAUSES OF COLLEGE STUDENTS IN PRIVATE COLLEGES AND UNIVERSITIES}

The psychological problems of the common between the college students and the public-run college students in the run-run colleges and universities, and the outstanding characteristics, should not only analyze the common problems, but also solve the personality problems, and then analyze and solve the problems, respectively. It is an important way to solve the psychological problems of the college students in the private university.

\section{A. Common Psychological problems with Public Colleges} and Universities

1) College freshmen have role change and adaptation obstacles

After entering the college entrance examination, many freshmen are faced with living alone and far from their parents. College freshmen must complete the transition from middle school students to college students and adapt to college life. Freshman year is the high incidence period of various psychological problems for college students, and enters the psychological imbalance period of freshmen [3]. There are many reasons for the psychological imbalance of freshmen. First of all, there is a gap between ideal and reality, and there is a gap between the university and the imaginary university, which is inconsistent with the college entrance examination motivational language of "just enter the university", resulting in a certain psychological gap; secondly, the university environment, interpersonal relationship and teaching model are all new to freshmen. Not very suitable, resulting in confusion and psychological disorders; students who can enter the university, the level is equal, their own outstanding sense of superiority does not exist, there is a certain psychological gap. 
2) College students have difficulty in dealing with the world.

Many college students around "classroom, dormitory, canteen" three-point life learning style, bell ring in and out of the classroom, dormitory without saying nothing, canteen countersink, communication on the Internet, in reality, do not want to communicate with people, nor know communication skills and principles, team awareness, become a "lonely" person, even appear self-closing tendency. The reason is not only two points, first, family education problems, parents care too well, students do not grow independently; The second is the lack of targeted university training due to environmental impact.

\section{3) College students rely too much on the Internet}

With the development of science and technology, the Internet has become an important part of modern life. Many business development cannot be separated from the network, especially wechat, qq and other chat tools have become a means for college students to communicate with each other, many college students indulge in the virtual network, attracted by the wonderful network, find the comfort of the mind in the virtual world, self-closure, and real life estrangement, unwilling to communicate with people face to face. Unsatisfactory in real life, relying on the virtual world, will inevitably produce psychological problems. One reason is that students fail to understand the value of the network. Second, the lack of school and family supervision, the need to correctly guide students to use the network.

\section{4) There is pressure on College students' study and Life}

When the college entrance examination volunteered to fill in, many students did not know much about the school and major. When they arrived at the university, they found that the university was not the university they imagined, and the major was not their favorite major, which made them feel very painful and under great pressure. Due to the change of learning methods, learning can not keep up with, the burden of curriculum is large, but also some students are too nervous for a long time, resulting in psychological pressure. Lack of ability to live alone can also bring pressure, as well as some families poverty, to solve the tuition and cost of living problems, can also cause psychological stress. With the liberalization of the second child policy, parents will also have a second child, which will also cause psychological pressure on the students.

\section{B. Special Psychological problems of College students in Private Colleges and Universities}

1) The emergence and causes of College students' inferiority complex Psychology

The students in private colleges and universities have serious inferiority complex psychological problems, which seriously affect the study and life of students, which is a more prominent psychological problem for students in private colleges and universities [4]. The main reason for inferiority complex is that the degree of social recognition of private colleges and universities is not high. Because of the unsatisfactory results of college entrance examination, students are forced to come to private colleges and universities. Compared with other students entering public schools, they have a greater sense of psychological difference, and even dare not tell others that they are studying in that school, afraid of being looked down upon by others, resulting in inferiority complex. In fact, the students who enter private universities are because they do not master the appropriate learning methods when they study in high school. Poor bundles, subjective lack of effort or environmental impact and many other factors, is not entirely a problem of their own ability, graduates of private colleges and universities also have a lot of industry elites.

2) The emergence and causes of College students' anxiety Psychology

In the face of academic and future employment and life pressure, private college students generally have anxiety, which brings some difficulties to their life and study. This kind of anxiety is caused by the inconsistency between learning expectations and learning results, which has the characteristics of typical fear psychology and has a strong negative side. In addition, by comparing the students of private colleges and universities with those of public colleges and universities, it is found that there is a gap between private college students and public colleges, especially in the aspects of teachers, future employment, postgraduate entrance examination and so on. They think that they will not catch up with the students of public colleges and universities no matter how hard they try, thus aggravating the psychological state of anxiety. In this state of mind, it leads to some private people. College students do not study actively, do not listen carefully, do not finish their homework on time, abandon themselves, and waste their good college time. This anxiety must be dredged and corrected in time to avoid affecting students' study and life.

\section{COUNTERMEASURES TO SOLVE THE PSYCHOLOGICAL PROBLEMS OF COLLEGE STUDENTS IN PRIVATE COLLEGES AND UNIVERSITIES}

It is a systematic project to solve the psychological problems of college students in private colleges and universities. We must accurately grasp the core of the problems, work hard from the emergence of the problems, analyze the causes, solve the problems, do a good job in management and control, give full play to the educational function of the school, society and family, guard against common problems in time, and do a good job in the work of one person and one person in time to resolve the psychological problems of students in time.

\section{A. The overall Thinking of solving Problems}

The core task of solving psychological problems in private colleges and universities is to solve the confusion of students, improve students' cognitive ability, actively create a good atmosphere for students to study and live, and train qualified socialist constructors and successors. Overall thinking: as the main body of education and teaching, the school should improve the teaching environment, carry out psychological education and teaching activities, construct psychological education platform and team, prevent and resolve the occurrence of students' psychological problems; the government should increase the supervision and investment of private colleges and universities, the society should provide more jobs for the graduates of private colleges and universities, students should strengthen their self-cultivation, improve their compressive ability, and the family should cooperate with the school to do a good job of students' ideological work. Will 
learn Only by comprehensively considering the school, society, family and students themselves, and solving students' psychological problems from their respective functions, can we get the expected results.

\section{$B$. Concrete measures to solve the problem}

1) To give full play to the role of Private Colleges and Universities as the main position to solve students' Psychological problems

As the main position of solving students' psychological problems, the university, which is educated by education, can not be replaced by society and family. Private colleges and universities should adopt feasible methods to construct the management system of psychological education.

The psychological problems of students are regarded as the content of school education management, and a sound psychological consultation organization is established. Private colleges and universities should change the practice of teaching only knowledge and skills, unify knowledge transfer and ideological education, and firmly grasp the root of foster talents. The leaders of private colleges and universities should pay attention to the psychological problems of students, mobilize all the teaching staff to investigate and find out the psychological problems of students, especially strengthen the construction of counselors, master the psychological problems of students, and help students solve these problems. Divide the psychological work from the ideological and political work, set up a special mental health education department, establish and improve the psychological consultation room, and help to improve the psychological problems. Help and service to improve the quality of personnel training.

Optimize the teaching content of psychological course, strengthen self-management and guidance. In private colleges and universities, mental health education should be brought into the curriculum system of students' general education, and mental health education should be set up as a compulsory course for all students. In the design of curriculum content, it is necessary to pay close attention to the reality of college students' psychological problems, to be targeted and timely, and to adopt the form and method which are easy for students to accept in teaching methods and methods, such as case type, seminar type and so on. Through the course study and popularizing the mental health knowledge, it also helps the students to learn to shape the healthy personality and emotional management, and applies the learned knowledge to the interpersonal relationship management, so as to be able to recognize objectively in the study work. To understand and deal with all kinds of affairs, to guide college students to guide themselves to the existing psychological problems, and to alleviate the psychological problems of college students.

Build a multi-level service platform to solve psychological problems with rich amateur cultural life. First, the construction of psychological service publicity platform. Using the website of Mental Health Education Center, WeChat Public platform, micro-blog interaction and other new media forms, to promote mental health knowledge, mental health education service content, so that students can eliminate the prejudice and misunderstanding of psychological consultation. The second is to carry out rich and colorful cultural life, organize all kinds of amateur activities according to the characteristics of the school, distract students' attention, alleviate the pressure of students' study, life and employment, expand students' communication circle, promote students' all-round development, establish a correct outlook on life, world outlook and values.

\section{2) Psychological problems of College students need Social} help

Society needs to increase the sense of identity of private college students and provide them with equal opportunities. First, the society should increase the recognition of private colleges and universities, do not label and mark the students of private colleges and universities, dilute the word "private" as far as possible, and treat the students of public universities and private universities equally. Second, to give equal opportunities in employment, postgraduate entrance examination and other aspects, the government can give better support and help to private college students in the aspect of independent entrepreneurship; employers should not distinguish between private colleges and public colleges and universities, give private college students a loose employment environment, can go to private colleges and universities to carry out special job fairs to solve the employment problem.

Improve the funding system and pay attention to ideological guidance. The family economic environment and poor economic conditions are the reasons for the psychological problems of some college students in private colleges and universities. This part of the college students have a sense of inferiority, can not communicate peacefully with others, and have no self-confidence. The establishment of financial aid system is an important means to solve this psychological problem. Colleges and universities, society and government should give full play to their trinity financial aid system, keep up with the pace of national poverty alleviation, help families of students with difficulties to get rid of poverty and help students complete their studies. On the basis of economic poverty eradication, we should strengthen ideological guidance help students to get rid of poverty, and let students set up lofty ideals and aspirations.

\section{3) Give full play to the subjective initiative of students}

College students are the main body of psychological problems. Under the impetus of the outside world, the subject should give full play to subjective initiative, strengthen self-cultivation, strengthen self-forging, comprehensively improve compressive ability, and pay attention to self-cracking psychological problems.

Strengthen personal accomplishment and make clear learning goals. The goal is direction and power. Under the guidance of teachers, college students in private colleges and universities should set up correct life goals, formulate university learning goals and plans, and strengthen their self-cultivation. Self-cultivation includes cultural basic literacy and professional literacy, which are reflected in the university curriculum system. Students should focus on the improvement of the two qualities, turn their energy to learning, and lay a solid foundation for their future study work. On the basis of learning general courses well, cultural basic literacy should also read more classic books and cultivate their own interests and specialties. While learning book knowledge well, 
professional literacy should actively carry out practice. Activities, apply book knowledge to practice, use learning instead of worry, solve psychological problems.

Strengthen the cultivation of self-control, improve personal willpower and psychological tolerance. Self-control is an important part of psychology. Mastering the method of self-control and doing a good job of self-management is an important content to solve the psychological problems of college students. First, to learn the self-control training methods, set up a self-control school, students can choose, no students can use network resources for self-study, and according to the method for self-exercise. Second, it is necessary to strengthen physical exercise and improve their own quality. Physical exercise is a good way for students to overcome inertia and cultivate willpower, and to choose long-term persistent items, such as long-distance running, can achieve the purpose of exercise. Third, we should strictly control it. The time to surf the Internet, play with mobile phones, the outside world and the Internet are full of temptation for college students, some people indulge in the Internet, form Internet addiction, quit Internet addiction, maintain learning enthusiasm, all need students to have high willpower. Fourth, it is necessary to actively adapt to the society and lay the foundation for future work, strengthen the cultivation of psychological affordability, and solve the competition and various pressures of the future society, so as to better serve the social development.

\section{CONCLUSION}

With the popularization of higher education, private higher education plays a more and more important role in talent training, and it is more and more important to solve the mental health problems of students in private colleges and universities. Colleges and universities should systematically construct psychological education and management system, establish a perfect psychological education curriculum system, combine classroom education with daily management, establish psychological service team and serve students. In the process of educational management, we should use advanced modern educational ideas, innovate educational management methods and models, make full use of the Internet and various media platforms, effectively solve students' psychological problems and promote students' healthy growth. At the same time, it is necessary to give full play to society and The function of family education can create a good study and employment environment for college students, solve the psychological burden of students, and really cultivate qualified socialist constructors and successors with the all-round development of morality, intelligence, body, beauty and labor.

\section{ACKNOWLEDGMENT}

Author brief introduction: Wang Shuqi (1998.05 -), female, undergraduate, major: radio and television director.

Corresponding author: Zhu guangliang, Deputy Director, Scientific Research Management Center

\section{REFERENCES}

[1] http://www.moe.gov.cn/jyb_xxgk/s5743/s5744/201906/t20190617_3862 $00 . \mathrm{htm}$

[2] Zhao Qiong. Research on Mental Health Education of College students in Private Colleges and Universities[J].Journal of Higher Education. 2018(7):159-161

[3] Xiong Sibin. Analysis on Mental Health problems and Countermeasures of College students in Private Colleges and Universities in the New period[J].Think Tank Era. 2018(45):71-72

[4] Li Mingxuan, Song Xiuhan. A study on the particularity and Countermeasures of Psychological problems of College students in Private Colleges and Universities[J].Modern Economic Information.2019(18):474-474.

[5] Lou Shili, Qian Shuifang. A study on the Psychological characteristics and intervention Countermeasures of students in Private Colleges and Universities[J].The Theory and Practice of Innovation and Entrepreneurship.2018(23):101-102.

[6] Liang Hong. Analysis and Countermeasures of Common Psychological problems of Contemporary College students[J].Journal of Hubei Open Vocational College, 2019(7):53-54 